\title{
Nevrofysiologisk monitorering under kirurgi
}

\begin{abstract}
BAKGRUNN Intraoperativ nevrofysiologisk monitorering har fått økende betydning ved operasjoner som innebærer risiko for skade på nervesystemet. Vi ønsker å gi en oversikt over muligheter og begrensninger ved bruk av intraoperative nevrofysiologiske metoder.
\end{abstract}

KUNNSKAPSGRUNNLAG Artikkelen bygger på en gjennomgang av aktuelle lærebøker og artikler fra eget litteraturarkiv, selektive søk i PubMed samt egne kliniske erfaringer.

RESULTATER Intraoperativ nevrofysiologisk monitorering omfatter både kontinuerlig overvåking av nervevev og lokalisering av vitale nevrologiske strukturer. Slik monitorering kan redusere risiko for skader på nerver og nervebaner og er mest brukt ved skolioseoperasjoner og nevrokirurgiske operasjoner. Behovet for nevrofysiologisk monitorering påvirker valg av anestesimetode, ettersom noen anestetika påvirker monitoreringen.

FORTOLKNING Intraoperativ nevrofysiologisk monitorering er avhengig av godt samarbeid mellom nevrofysiologer, kirurger, anestesiologer og andre involverte spesialiteter.

I løpet av de siste 30 år har intraoperativ nevrofysiologisk monitorering utviklet seg fra å være en interessant undersøkelsesmetode til å bli en akseptert og vanlig benyttet metode for å beskytte pasienten mot nevrologiske skader under operasjoner (1). Spesielt ved skolioseoperasjoner og nevrokirurgiske operasjoner er intraoperativ nevrofysiologisk monitorering blitt rutine ved mange sentre.

I denne artikkelen gir vi en oversikt over muligheter og begrensninger ved bruk av intraoperative nevrofysiologiske metoder, spesielt anvendelse ved ortopediske og nevrokirurgiske operasjoner.

\section{Kunnskapsgrunnlag}

Artikkelen bygger på en gjennomgang av aktuelle lærebøker og artikler, hovedsakelig fra eget litteraturarkiv og selektive søk i PubMed, deltakelse på internasjonale kurs og kongresser, utdanningsprogram arrangert av den internasjonale foreningen for intraoperativ nevrofysiologisk monitorering (The International Society of Intraoperative Neurophysiology), studiereiser til utenlandske sentre med erfaring med metodene samt vår egen kliniske erfaring med slik monitorering ved ortopediske og nevrokirurgiske operasjoner.

\section{Hva er intraoperativ nevrofysiologisk monitorering?}

Intraoperativ nevrofysiologisk monitorering omfatter mange prosedyrer som har som mål å overvåke funksjonen i nevronale strukturer under kirurgiske inngrep (tab 1). Metoden brukes der det er risiko for å skade nervevev (sentrale nervebaner, perifere nerver) under operasjoner. Man skiller mellom to metoder:

- Kontinuerlig overvåking gjør at man kan se tegn til begynnende skade på nervevev på et tidspunkt der det er mulig å reversere skaden.
- Lokalisasjonsteknikk (mapping) gjør at man kan finne vitale nevrologiske strukturer som ellers er vanskelig å skille fra omkringliggende vev.

\section{Utvikling av metodene}

Wilder Penfield (1891-1976) var den første som begynte med direkte kortikal stimulering av motorisk cortex (øvre motornevron) hos pasienter (2). Med unntak av intraoperativ nevrofysiologisk monitorering for å lokalisere epileptiske foci, skjedde det lite inntil 1950- og 60-årene. Bruk av somatosensorisk fremkalt respons (somatosensory evoked potentials, SEP) begynte å bli rutine ved skolioseoperasjoner i 1970-årene. Selv om de første monitoreringer av $\mathrm{n}$. facialis ble gjennomført allerede i 1960-årene, var det først i 1980-årene at man begynte å bruke elektromyografi (EMG) og hjernestammeresponser, auditiv fremkalt respons (brainstem auditory evoked response, BAER) ved kirurgi i bakre skallegrop. Fra ca. 1990 ble motorisk fremkalte potensialer (motor evoked potentials, MEP) i økende grad benyttet til å overvåke motoriske baner ved operasjoner.

\section{Metodene}

Ved hjelp av motorisk fremkalte potensialer overvåkes motoriske baner (tractus corticospinalis). I intraoperativ diagnostikk stimulerer man alfamotornevroner i cortex ved hjelp av transkranial elektrisk stimulering (TES) (illustrasjon 1). Ved kraniotomi kan også direkte kortikal stimulering gjennomføres. Motorisk fremkalte potensialer blir avledet fra distale muskler i over- og underekstremiteter ved hjelp av nålelektroder. Ved spinale operasjoner overvåkes først og fremst om et signal er til stede (alt eller intet). Dersom et reproduserbart signal er til stede, er det tegn på funksjonell integritet av

\author{
Ralf Peter Michler \\ ralf-peter.michler@stolav.no \\ Avdeling for nevrologi og klinisk nevrofysiologi \\ St. Olavs hospital \\ Geirmund Unsgård \\ Nevrokirurgisk avdeling \\ St. Olavs hospital \\ og \\ Institutt for nevromedisin \\ Norges teknisk-naturvitenskapelige universitet \\ Ivar Rossvoll \\ Ortopedisk avdeling \\ St. Olavs hospital \\ og \\ Institutt for nevromedisin \\ Norges teknisk-naturvitenskapelige universitet
}

\section{HOVEDBUDSKAP}

Nevrofysiologisk monitorering under kirurgi kan redusere risiko for skader på nerver og nervebaner

Man skiller mellom kontinuerlig overvåking av nervevev og lokalisasjonsteknikk for å finne vitale nevrologiske strukturer

Slik monitorering er mest brukt ved nevrokirurgi og skolioseoperasjoner 

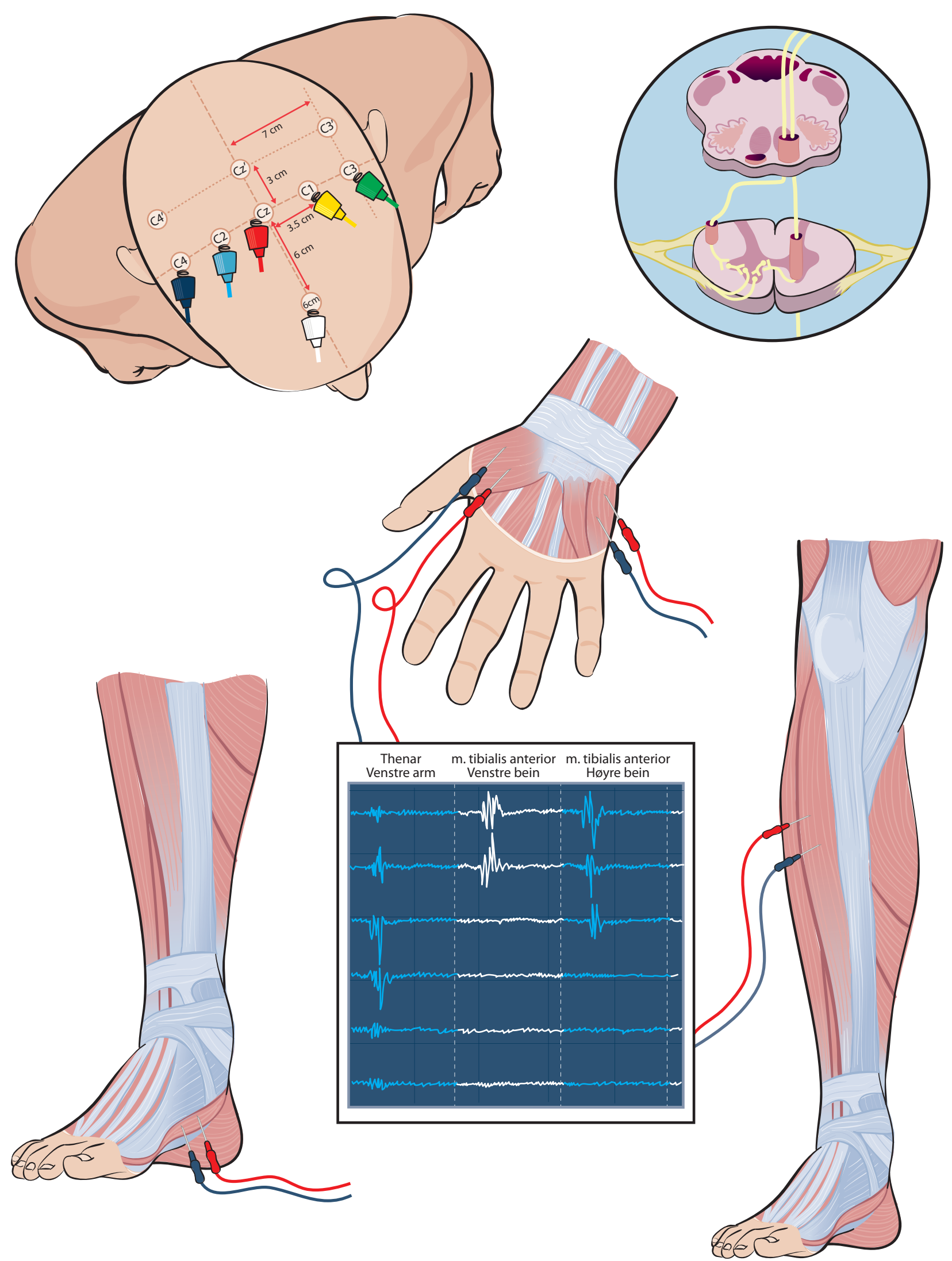

Illustrasjon 1 Motorisk fremkalte potensialer (MEP) er en metode for å overvåke motoriske baner (tractus corticospinalis, øverst til høyre). Alfa motonevroner i hjernebarken stimuleres ved transkranial elektrisk stimulering (øverst til venstre). Motorisk fremkalte potensialer blir avledet fra distale muskler ved hjelp av nålelektroder. Illustrasjonen viser avledning fra musculus abductor digiti minimi og thenar (midterst), fra musculus abductor hallucis (nederst til venstre) og fra musculus tibialis anterior (nederst til høyre). Skjermbildet viser plutselig tap av motorisk fremkalte potensialer fra begge underekstremitetene ved kirurgi i torakalcolumna. Motorisk fremkalte potensialer fra musculus tibialis anterior venstre og høyre bein forsvinner med bevart potensial fra venstre thenar. Dette indikerte en truende spinal skade, operasjonen ble avsluttet og pasienten hadde etter operasjonen forbigående noe redusert funksjon i underekstremitetene. Illustrasjon $\odot \mathrm{J}$. Engqvist/lllumedic 

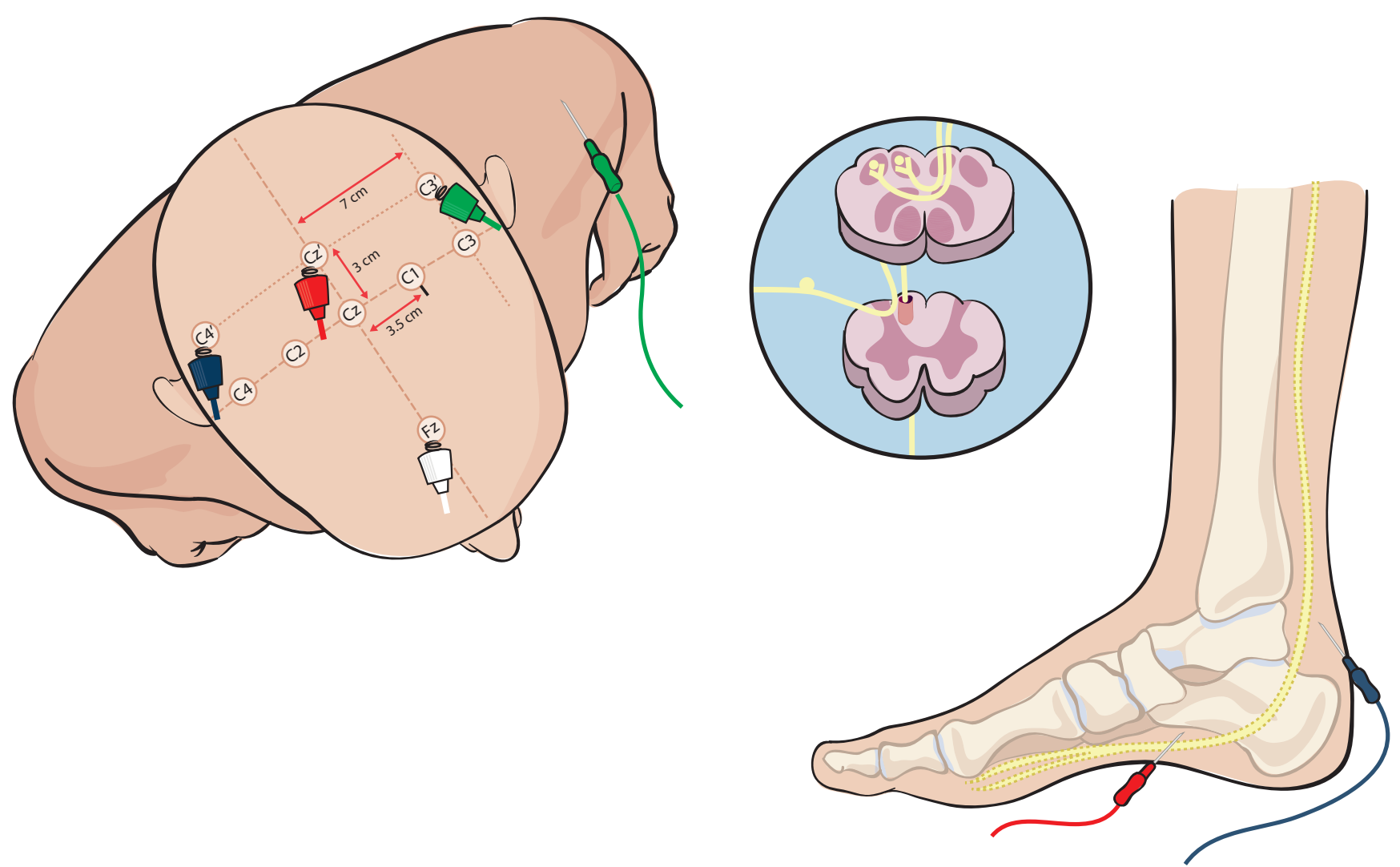

Illustrasjon 2 Somatosensorisk fremkalt respons brukes for å overvåke bakstrengsystemet (lemniscus medialis) i ryggmargen. Illustrasjonen viser elektrisk stimulering av n. tibialis og avledning fra sensoriske cortex (Cz-Fz). Illustrasjon $\odot \mathrm{J}$. Engqvist/lllumedic

motoriske baner, og man kan forvente at pasienten våkner uten parese etter en spinal operasjon (3). Ved hjerneoperasjoner har amplitudevariasjoner større betydning (4).

Somatosensorisk fremkalt respons brukes for å overvåke bakstrengsystemet (lemniscus medialis) i ryggmargen. Metoden skiller seg lite fra det man bruker i vanlig diagnostikk. Man stimulerer nervene (nervus medianus eller nervus tibialis) elektrisk, og responsene avledes fra sensorisk cortex (illustrasjon 2). Vanligvis oppfattes en amplitudereduksjon på mer enn $50 \%$ som klinisk signifikant (5).

Med elektromyografi overvåkes hjernenerver, perifere nerver, plexus brachialis, plexus lumbosacralis og spinale motoriske nerverøtter. Auditiv fremkalt respons brukes til å overvåke funksjonen i åttende hjernenerve og i hjernestammen. Elekroencefalografi (EEG) brukes til å overvåke hjernefunksjonen.

\section{Deformitetskirurgi \\ i torakolumbalcolumna}

Ved operasjoner for deformiteter i torakolumbalcolumna er nevrologisk skade den mest fryktede komplikasjonen. Det nevrologiske utfallet kan være alt fra lette sensoriske forstyrrelser til komplett tverrsnittslesjon.

Den største gruppen pasienter som opereres for deformiteter i ryggsøylen er ungdommer med idiopatisk skoliose. Det typiske er at operasjonen utføres tidlig i tenårene dersom skoliosevinkelen passerer $45-50^{\circ}$ målt med Cobbs metode (vinkelen målt mellom øvre dekkplate på øvre virvel og nedre dekkplate på nedre virvel i kurven). Insidensen av nevrologiske komplikasjoner ved denne typen deformitetskirurgi i ryggsøylen er av Scoliosis Research Society estimert til < $1 \%(6)$.

Skade på ryggmargen kan oppstå både som følge av mekanisk påvirkning, ved korreksjon av feilstillingen og som følge av hypoksi på bakgrunn av nedsatt blodforsyning. Faktorer som man regner med kan øke risikoen for nevrologisk skade er blant annet skoliose kombinert med hyperkyfose, kongenital skoliose og store skolioser med den såkalte «Cobbs vinkel» over $90^{\circ}$ (7). Videre kan nedsatt perfusjon av ryggmargen på grunn av hypotensjon og/eller betydelig peroperativ blødning føre til nevrologisk skade.

Før bruk av moderne intraoperativ monitorering var «Stagnara wake-up test» den eneste tilgjengelige metoden for å kontrollere pasientens ryggmargsfunksjon under inngrepet. Denne testen innebærer at pasienten vekkes under operasjonen og bes om å bevege på beina etter at feilstillingen er korrigert, men før såret lukkes og operasjonen avsluttes. Det er mange svakheter ved denne metoden: Narkosen må heves og pasienten må kunne samarbeide og bevege beina på kommando. Testen utføres på et gitt tidspunkt på slutten av inngrepet og gir ikke mulighet for kontinuerlig overvåking av ryggmargens funksjon.
Man får ikke kunnskap om når skaden oppsto eller hvilken manøver som utløste den. Muligheten for å reversere en truende nevrologisk skade kan da gå tapt $(7,8)$.

En undersøkelse basert på 51263 pasienter som ble operert for skoliose og overvåket med somatosensorisk fremkalte responser antydet en reduksjon i risiko for alvorlige nevrologiske skader på ca. $60 \%$ sammenliknet med historiske kontrollpersoner operert uten slik monitorering (9). Imidlertid var det fortsatt noen pasienter som fikk alvorlige nevrologiske utfall, selv om somatosensorisk fremkalte responser var normale under operasjonen (falskt negativ).

De motoriske baner i ryggmargen synes å være mer utsatt for skade enn de sensoriske, og spesielt gjelder dette ved hypoksi $(7,8)$. Schwartz og medarbeidere viste $i$ et stort materiale med 1121 skoliosepasienter at 38 hadde reduksjon i nevrofysiologiske signaler til under alarmnivå under operasjon (8). 17 hadde kun forandringer i motoriske potensialer (MEP), ikke i somatosensoriske (SEP). Hos de sju pasientene som hadde motoriske utfall etter inngrepet, var motoriske potensialer redusert til under alarmnivå peroperativt hos alle, mens somatosensorisk respons var normal hos fire av de sju. Det er verdt å merke seg at det nevrologiske utfallet hos alle pasientene i denne studien normaliserte seg i løpet av 24 timer til 90 dager postoperativt. Man kan spekulere i om dette skyl- 
des at det kunne iverksettes umiddelbare tiltak ved truende ryggmargsskade på grunn av tidlige alarmsignaler fra registrering av motoriske potensialer under operasjonen. Forfatterne konkluderte med at registrering av motoriske potensialer er mer sensitiv enn registrering av sensoriske potensialer og gir tidligere utslag ved truende peroperativ ryggmargsskade slik at tiltak kan iverksettes før skaden blir permanent.

Registrering av funksjon i motoriske baner og somatosensoriske baner vil, sammenliknet med registrering av somatosensorisk baner alene gi et sikrere og tidligere varsel om at ryggmargen er truet, slik at operatør og anestesipersonell umiddelbart kan sette i verk tiltak for å reversere dette. Tiltak kan være heving av blodtrykk, pause i operasjonen, reversering av korreksjon og eventuelt fjerning av innsatte implantater (8). Kombinasjonen av metodene viser en meget høy sensitivitet og spesifisitet med henblikk på å oppdage begynnende nerveskade under operasjon (10), og bruk av begge blir nå oppfattet som gullstandard (11). Den tidligere brukte «Stagnara wake-up test» anses ikke lenger nødvendig som rutine når det benyttes intraoperativ nevrofysiologisk monitorering ved deformitetskirurgi $(10,11)$.

Intraoperativ nevrofysiologisk monitorering brukes også ved andre typer ryggkirurgi. Blant annet kan stimulert elektromyografi brukes for å unngå iatrogene skader ved kompliserte spinale operasjoner med pedikkelskrue og ved selektiv dorsal rhizotomi $(12,13)$.

\section{Operasjon}

\section{av intramedullær spinal tumor}

Operasjon av intramedullær spinal tumor innebærer en høy risiko for skade av nervevev. Paralyse/parese er den mest fryktete komplikasjonen, og det er derfor svært viktig å ha en diagnostisk mulighet til å måle direkte den funksjonelle integriteten av det motoriske systemet. Intraoperativ monitorering ved hjelp av motorisk og somatosensorisk fremkalte potensialer er optimale midler for å oppnå dette målet (14).

Det viktigste man måler er tilstedeværelse eller fravær av motoriske potensialer (illustrasjon 1). Kombinasjon av muskelpotensial med D-bølge, som er et såkalt direkte signal som avledes ved hjelp av et intraduralt kateter distalt for operasjonsstedet, kan ytterligere $ø$ ke diagnostisk presisjon (15). Tilstedeværelse av muskelpotensialer er $100 \%$ spesifikt for intakt motorisk funksjon etter operasjonen. Når muskelpotensial forsvinner, tyder det på postoperative motoriske utfall i ca. $90 \%$ av tilfellene (15).

Sala og medarbeidere fant at monitorering med motorisk fremkalte potensialer forbedret resultatet av intramedullære tumoroperasjoner sammenliknet med historiske kontrollpersoner uten slik monitorering (16). Mye taler for at nevrokirurgene opererer mer radikalt med monitorering (15), men pros-

Tabell 1 Operasjoner der det er aktuelt med intraoperativ nevrofysiologisk monitorering og metoder som hovedsakelig brukes

\begin{tabular}{ll} 
Type kirurgi & Metode for monitorering \\
Nevrokirurgi & \\
Vestibularisschwannom & Elektromyografi \\
& Auditivt fremkalt respons \\
Infratentorielle hjernetumorer & Elektromyografi \\
& Auditivt fremkalt respons \\
& Eventuelt: somatosensorisk fremkalt respons \\
& og motorisk fremkalte potensialer \\
\hline Supratentorielle hjernetumorer & Somatosensorisk fremkalt respons \\
& Motorisk fremkalte potensialer \\
& Direkte kortikal stimulering \\
Spinale tumorer & Motorisk fremkalte potensialer \\
& Somatosensorisk fremkalt respons \\
Cerebrale aneurismer & Somatosensorisk fremkalt respons \\
Kirurgi i nervepleksus/ & Motorisk fremkalte potensialer \\
perifere nerver & Elektromyografi (mappingl \\
\hline
\end{tabular}

\section{Ortopedi}

Skoliosekirurgi

Motorisk fremkalte potensialer

Somatosensorisk fremkalt respons

Annen komplisert spinalkirurgi Elektromyografi

Pedikkelskruetest

\section{Karkirugi}

Endarterektomi i arteria carotis interna

Somatosensorisk fremkalt respons Elektroencefalografi

Torakale aortaaneurismer

Motorisk fremkalte potensialer

Somatosensorisk fremkalt respons

pektive randomiserte studier finnes foreløpig ikke og er vanskelig å gjennomføre av etiske og juridiske årsaker (17).

Ved påvirkning av motorisk fremkalte potensialer (potensialene forsvinner eller får plutselig amplitudereduksjon) kan en pause i operasjonen og skylling med saltvann føre til normalisering. Dette kan ta flere minutter. Blodtrykksøkning kan også ha samme effekt (18). Ved amplitudereduksjon kan det også være en fordel å forandre reseksjonslokalisasjonen.

Når den nevrofysiologisk aksepterte grensen er nådd (tap av motorisk fremkalte potensialer, D-bølge reduksjon $50 \%$ ), må operasjonen avsluttes for å redusere risikoen for lammelser. Det kan være indikasjon for å gjøre ny operasjon etter rekonvalesensfasen. På den annen side gir stabile motorisk fremkalte potensialer støtte for kirurgen til å fortsette med operasjonen (19).

Multimodal intraoperativ monitorering ved spinale intramedullære tumoroperasjoner og ved kompliserte ekstramedullære intradurale tumoroperasjoner er anbefalt av en europeisk konsensusgruppe (11).

\section{Kirurgi i conus- og caudaregionen}

Uttrykket «tethered cord», tjoret ryggmarg, betegner forskjellige tilstander som har til felles at det foreligger en patologisk fiksering av ryggmargen $\mathrm{i}$ abnorm lokalisasjon, med den følge at ryggmargen settes på strekk. Årsaken kan være myelomeningocele, abnorm filum terminale, spinal tumor (lipom), spinal dermoid cyste samt andre okkulte spinale dysrafier.

Mange pasienter får symptomer i barndommen, mens andre først får dette i voksen alder (20). Hovedsymptomene er ryggsmerter, nevrologiske utfall i beina og urologiske forstyrrelser. Risiko for postoperative permanente nevrologiske utfall er opptil 4,5\% $(21,22)$. Målet med operasjonen er å frigjøre conus medullaris og cauda equina fra abnorme fibrøse bånd, lipomer og fra ikkefunksjonelt nervevev. Verdien av preoperativ magnetisk resonanstomografi kan være 


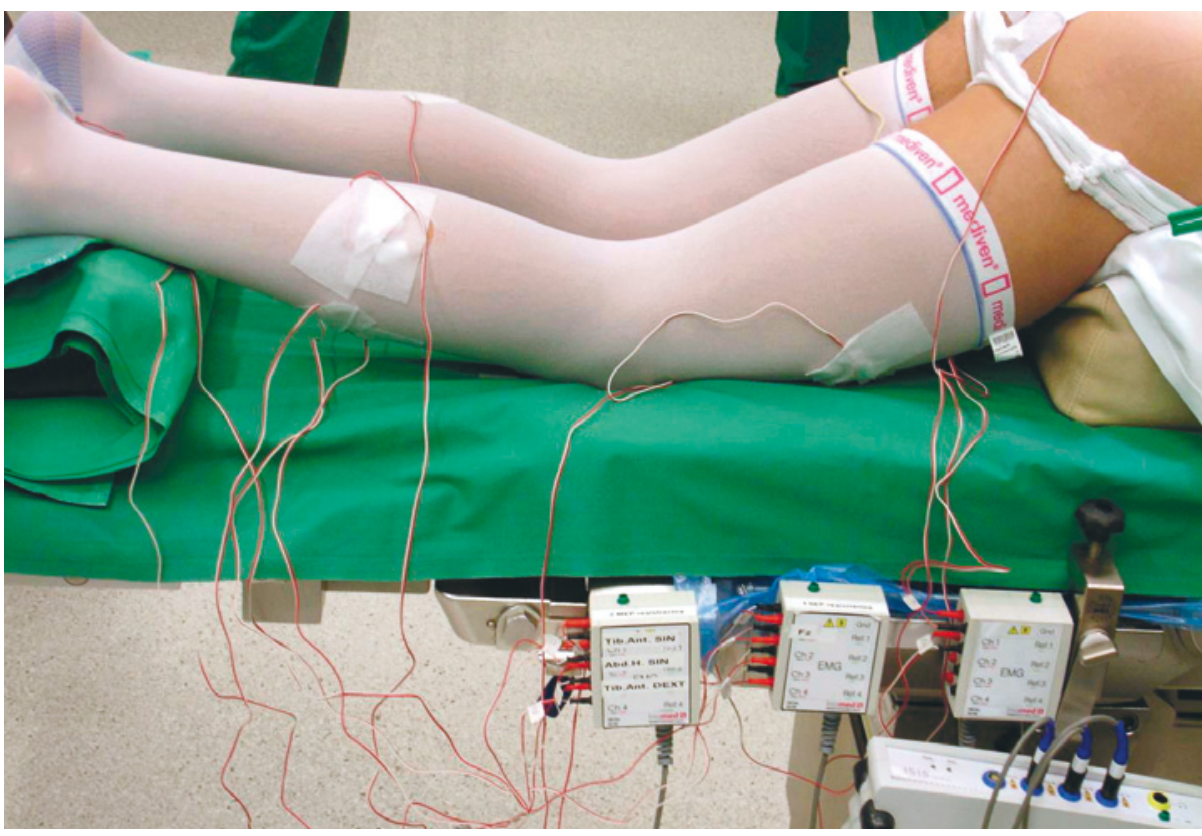

Figur 1 Monitorering hos en pasient med tethered cord-syndrom. Ved hjelp av nåleelektroder måles signaler bilateralt fra $m$. tibialis anterior, $m$. gastrocnemius, $m$. vastus lateralis, $m$. abductor hallucis og $m$. sphincter ani

begrenset, siden undersøkelsen ikke kan gi informasjon om funksjonen av involverte strukturer (23). Ved operasjonen er det essensielt å skille mellom funksjonelle og ikke-funksjonelle strukturer for å unngå postoperative nevrologiske komplikasjoner.

Nevrofysiologisk monitorering har fått stor betydning ved denne type operasjoner og er blitt anbefalt av den europeiske konsensusgruppen (11). Viktigst er direkte elektrisk stimulering av strukturer i operasjonsområdet og avledning av muskelpotensialer fra muskler innervert av forskjellige nerver i beina og fra sfinkter ani (fig 1). Ved hjelp av slik kartleggingsteknikk (mapping) kan fungerende strukturer bli identifisert og bevart $(24,25)$. Somatosensorisk fremkalte responser av n. tibialis er av mindre betydning, fordi signifikante signalforandringer ved den type operasjoner er uvanlig, men undersøkelsene kan gi tilleggsinformasjon (26).

I en studie med 44 pasienter operert for tjoret ryggmarg hadde EMG-monitorering $100 \%$ sensitivitet, men en lav spesifisitet med $19 \%(27)$.

Intraoperativ nevrofysiologisk monitorering av bulbocavernosusrefleks er en metode som gir informasjon om de sakrale ryggmargssegmentene $\mathrm{S} 2$ til $\mathrm{S} 4$ og den afferente og efferente delen av nervus pudendus (28). Den prognostiske verdien er fortsatt noe usikker (29).

\section{Monitorering av hjernenerver}

Nesten all hjernenervemonitorering bygger på erfaringer fra monitorering av facialisnerven ved operasjon av vestibularisschwannom. Monitorering skjer ved hjelp av kontinuerlig elektromyografi og elektrisk stimulering av nerven (finkartlegging (mapping)). Man registrerer fra minst to facialisinnerverte muskler. Der det foreligger bevart hørsel, bør også auditiv fremkalt respons gjennomføres. Ved hjelp av monitorering bør permanent facialisparese etter operasjon for vestibularis schwannom være et sjeldent unntak (30).

Alle motoriske hjernenerver kan monitoreres. Som ved facialisnervemonitorering skjer monitorering av de andre motoriske hjernenervene ved hjelp av kontinuerlig EMG og elektrisk stimulering av nerven med EMG-avledning fra spesifikke muskler. Finkartlegging er viktigst fordi spontanaktivitet har usikker prognostisk verdi (31). Det er også mulig å identifisere motoriske hjernernervekjerner ved finkartlegging under operasjoner i hjernestammen, 4. ventrikkel og i fossa rhomboidea (32).

\section{Kortikale operasjoner}

Monitorering blir brukt ved operasjoner i sentralregionen (gyrus precentralis og gyrus postcentralis) hos utvalgte pasienter. Somatosensorisk fremkalte responser kan hjelpe nevrokirurgen med å identifisere sentralregionen intraoperativt. Somatosensorisk fremkalte responser med direkte kortikal avledning i postcentralregionen og motorisk fremkalte potensialer med kortikal stimulering i precentralregionen kan redusere risiko for nevrologiske utfall (33). Direkte kortikal stimulering hos våkne pasienter kan være med på å identifisere språkregionen $(34,35)$.

I den foreløpig største studien med subkortikal språkkartlegging opererte Duffau og medarbeidere 115 pasienter med lavgradige gliomer i dominant hemisfære (36). Hos våkne pasienter identifiserte de subkortikale språkstrukturer. Det kliniske resultatet var bra hos $98 \%$ av pasientene, og ved MRkontroll var $83 \%$ av reseksjonene totale eller subtotale. Prospektive randomiserte studier mangler.

\section{Vaskulære operasjoner}

Monitorering med somatosensorisk og motorisk fremkalte potensialer blir brukt ved kompliserte cerebrale aneurismeoperasjoner og ved operasjon av arteriovenøse malformasjoner. Ved supratentoriell kirurgi kan kontinuerlig tibialis-SEP-monitorering brukes ved aneurisme utgående fra arteria cerebri anterior og medianus-SEP ved aneurisme utgående fra arteria cerebri media (33).

Ved noen sentre brukes EEG og medianusSEP til overvåking av kortikale funksjoner ved carotisendarterektomi (37). Motorisk fremkalte potensialer kan redusere risikoen for paraplegi ved aortaoperasjoner $(38,39)$.

\section{Anestesi og intraoperativ nevrofysiologisk monitorering}

Inhalasjonsanestetika, hypnotika og opiater demper uspesifikt synaptiske og aksonale funksjoner i nevronene, reduserer potensialamplituden og øker potensiallatensen ved EEG og motorisk og somatosensorisk fremkalte potensialer. Ved bruk av inhalasjonsanestetika er det stor risiko for at man ikke får noen svar på motorisk fremkalte potensialer (40). Alle hypnotika reduserer motoriske potensialer mer enn somatosensoriske potensialer. Muskelrelaksantia blokkerer den nevromuskulære transmisjonen. Propofol har mindre sentralnervøst dempende effekt enn inhalasjonsanestetika og blir derfor foretrukket ved operasjoner der man benytter monitorering av motorisk eller somatosensorisk fremkalte potensialer. Høye propofoldoser kan påvirke svaret for motorisk fremkalte potensialer (41).

Anbefalt er derfor total intravenøs anestesi (TIVA) i form av en kombinasjon av propofol og remifentanyl når det benyttes monitorering av motorisk eller somatosensorisk fremkalte potensialer under operasjonen. Hypovolemi, hypotoni og temperaturfall kan også påvirke potensialene. Ved operasjoner der det kun monitoreres ved hjelp av EMG, kan inhalasjonsanestetika benyttes.

Ved MEP- eller EMG-monitorering bør muskelrelaksantia ikke brukes i monitoreringsperioden, men kun ved innledningen av anestesien (42).

Godt samarbeid med anestesipersonalet er en forutsetning for en vellykket monitorering.

\section{Pasientsikkerhet}

Vår erfaring er at det generelt er liten risiko for skader som følge av intraoperativ nevrofysiologisk monitorering. Elektrisk hjernestimulering kan lage abnorme nevronale utladninger som kan føre til kliniske anfall. Dette er en kjent risiko ved høyfrekvent $(50-60 \mathrm{~Hz})$ stimulering (43). Lavfrekvent MEP-stimulering, som vi bruker, innebærer meget liten anfallsrisiko (44).

Ved bruk av MEP-stimulasjonselektroder er det beskrevet noen få lokale hudforbrenninger som skyldtes teknisk feil, samt tilfeller med tungebitt på grunn av kjevebevegelser 
(45). Tungebitt kan unngås ved rutinebruk av tungebeskyttelse. Relative kontraindikasjoner for motorisk fremkalte potensialer er epilepsi, intrakraniale elektroder, vaskulære klips, pacemaker og annet implantert biomekanisk utstyr (44).

\section{Avsluttende kommentarer}

Intraoperativ nevrofysiologisk monitorering kan redusere faren for nevrologiske skader ved ortopediske og nevrokirurgiske operasjoner. I land som Sverige, Finland og Sveits er det vanlig at universitetssykehus og til dels større regionale sykehus har et tilbud om intraoperativ nevrofysiologisk monitorering ved ortopediske og nevrokirurgiske avdelinger. Etterspørselen har også økt Norge. Samarbeid med andre fagområder (anestesi, operasjonspersonell, kirurger) er av stor betydning for resultatet. Nevrofysiologen bør ha god kommunikasjon med operatør og informere om muligheter og begrensninger ved nevrofysiologisk monitorering ved hver operasjon. Den europeiske konsensusgruppen anbefaler at det primært er en nevrofysiolog med tilleggsutdanning $\mathrm{i}$ intraoperativ nevrofysiologisk monitorering som er ansvarlig for monitoreringen (11). Pga. begrenset tilgang på nevrofysiologer $\mathrm{i}$ enkelte land er også andre spesialiteter, først og fremst nevrokirurger, involvert. Intraoperativ nevrofysiologisk monitorering er ressurskrevende, men kan forsvares også økonomisk $(46,47)$.

\section{Ralf Peter Michler (f. 1959)}

er spesialist i nevrologi og klinisk nevrofysiologi og overlege.

Forfatter har fylt ut ICMJE-skjemaet og oppgir ingen interessekonflikter.

\section{Geirmund Unsgård (f. 1948)}

er professor i nevrokirurgi og klinikksjef. Forfatter har fylt ut ICMJE-skjemaet og oppgir ingen interessekonflikter.

\section{Ivar Rossvoll (f. 1956)}

er konstituert avdelingsoverlege og førsteamanuensis.

Forfatter har fylt ut ICMJE-skjemaet og oppgir ingen interessekonflikter.

\section{Litteratur}

1. Nuwer MR. Intraoperative monitoring of neural function. Handbook of clinical neurophysiology. 8. utg. Atlanta, GA: Elsevier, 2008: 2-6.

2. Penfield W, Boldrey E. Somatic motor and sensory representation in the cerebral cortex of man as studied by electrical stimulation. Brain 1937; 60: $339-443$

3. Kothbauer KF, Deletis V, Epstein FJ. Motor-evoked potential monitoring for intramedullary spinal cord tumor surgery: correlation of clinical and neurophysiological data in a series of 100 consecutive procedures. Neurosurg Focus 1998; 4: e1.

4. Horiuchi K, Suzuki K, Sasaki T et al. Intraoperative monitoring of blood flow insufficiency during surgery of middle cerebral artery aneurysms. J Neurosurg 2005; 103: 275-83.

5. Nuwer MR. Evoked potential monitoring in the operating room. New York, NY: Raven Press, 1986: 246

6. Diab M, Smith AR, Kuklo TR. Neural complications in the surgical treatment of adolescent idiopathic scoliosis. Spine 2007: 32: 2759-63.

7. Pastorelli F, Di Silvestre M, Plasmati R et al. The prevention of neural complications in the surgical treatment of scoliosis: the role of the neurophysiological intraoperative monitoring. Eur Spine J 2011: 20 (suppl 1): 105-14.

8. Schwartz DM, Auerbach JD, Dormans JP et al. Neurophysiological detection of impending spinal cord injury during scoliosis surgery. J Bone Joint Surg Am 2007; 89: 2440-9.

9. Nuwer MR, Dawson EG, Carlson LG et al. Somatosensory evoked potential spinal cord monitoring reduces neurologic deficits after scoliosis surgery: results of a large multicenter survey. Electroencephalogr Clin Neurophysiol 1995: 96:6-11.

10. Eggspuehler A, Sutter MA, Grob D et al. Multimodal intraoperative monitoring during surgery of spinal deformities in 217 patients. Eur Spine J 2007: 16 (suppl 2): S188-96.

11. Sutter M, Deletis V, Dvorak J et al. Current opinions and recommendations on multimodal intraoperative monitoring during spine surgeries. Eur Spine J 2007; 16 (suppl 2): S232-7.

12. Balzer JR, Crammond D, Habeych M et al. Intraoperative EMG during spinal pedicle screw instrumentation. I: Nuwer MR, red. Intraoperative monitoring of neural function. Handbook of clinical neurophysiology. 8. utg. Atlanta, GA: Elsevier, 2008; 404-22.

13. Yingling CD. Selektive dorsal rhizotomy. I: Nuwer $M R$, red. Intraoperative monitoring of neural Func tion. Handbook of Clinical Neurophysiology. 8. utg. Atlanta, GA: Elsevier, 2008: 439-54.

14. Kothbauer K, Deletis V, Epstein FJ. Intraoperative spinal cord monitoring for intramedullary surgery: an essential adjunct. Pediatr Neurosurg 1997; 26 247-54

15. Kothbauer KF. Motor evoked potential monitoring for intramedullary spinal cord tumor surgery. I: Deletis V. Shils JL, red. Neurophysiology in neurosurgery. A modern intraoperative approach. Waltham, MA: Academic Press, 2002: 73-92.

16. Sala F. Palandri G, Basso E et al. Motor evoked potential monitoring improves outcome after surgery for intramedullary spinal cord tumors: a historical control study. Neurosurgery 2006 58: 1129-43, discussion 1129-43.

17. Sala F, Kothbauer KF. Intraoperative neurophysiological monitoring during surgery for intramedullary spinal cord tumors. I: Nuwer MR, red. Intraoperative monitorering of neural function. Hand book of clinical neurophysiology 8 utg Atlanta, GA: Elsevier 2008: 632-50

18. Sala F, Bricolo A, Faccioli F et al. Surgery for intramedullary spinal cord tumors: the role of intraoperative (neurophysiological) monitoring. Eur Spine J 2007: 16 (suppl 2): S130-9.

19. Jallo GI, Kothbauer KF, Epstein FJ. Intrinsic spinal cord tumor resection. Neurosurgery 2001; 49 1124-8

20. Iskander BJ, Oakes WJ. Occult spinal dysraphism. I: Albright AL, Pollack IF, Adelson PD, red. Principles and practice of pediatric neurosurgery. New York, NY: Thieme, 1999: 321-51.

21. Pang D, Wilberger JE Jr. Tethered cord syndrome in adults. J Neurosurg 1982: 57: 32-47.

22. Pierre-Kahn A, Zerah M, Renier D et al. Congenital lumbosacral lipomas. Childs Nerv Syst 1997; 13 298-334, discussion 335

23. Warder DE, Oakes WJ. Tethered cord syndrome and the conus in a normal position. Neurosurgery 1993: 33: $374-8$

24. Kothbauer KF, Deletis V. Intraoperative neurophysiology of the conus medullaris and cauda equina. Childs Nerv Syst 2010; 26: 247-53.

25. Sala F, Krzan MJ, Deletis V. Intraoperative monitoring in pediatric neurosurgery: Why, when, how Childs Nerv Syst 2002; 18: 264-87.

26. Khealani B. Husain AM. Neurophysiologic intraoperative monitoring during surgery for tethered cord syndrome. J Clin Neurophysiol 2009; 26 $76-81$

27. Paradiso G, Lee GY, Sarjeant L et al. Multimodal intraoperative neurophysiologic monitoring findings during surgery for adult tethered cord syndrome: Analysis of a series of 44 patients with longterm follow-up. Spine 2005; 31: 2095-102.
28. Deletis $V$ Vodusek DB. Intraoperative recording of the bulbocavernosus reflex. Neurosurgery 1997 40: 88-92, discussion 92-3.

29. Rodi Z, Vodusek DB. Intraoperative monitoring of the bulbocavernosus reflex: the method and its problems. Clin Neurophysiol 2001; 112: 879-83.

30. Samii M, Matthies C. Management of 1000 vestibular schwannomas (acoustic neuromas): the facial nerve-preservation and restitution of function. Neurosurgery 1997; 40: 684-94, discussion $694-5$

31. Schlake HP, Goldbrunner RH, Milewski $C$ et al. Intra-operative electromyographic monitoring of the lower cranial motor nerves (LCN IX-XII) in skull base surgery. Clin Neurol Neurosurg 2001 103: $72-82$

32. Eisner W, Schmid UD, Reulen H-J et al. The mapping and continuous monitoring of the intrinsic motor nuclei during brain stem surgery. Neurosurgery $1995 ; 37: 255-65$.

33. Neuloh G, Schramm J. Intraoperativ neurophysiological mapping and monitoring for supratentoria procedures. I: Deletis V, Shils JL, red. Neurophysiology in neurosurgery. A modern intaoperative approach. Waltham, MA: Academic Press, 2002; $339-401$

34. Ojemann G, Ojemann J, Lettich E et al. Cortical language localization in left, dominant hemisphere. An electrical stimulation mapping investigation in 117 patients. J Neurosurg 1989; 71: 316-26.

35. Sanai N, Berger MS. Intraoperative stimulation techniques for functional pathway preservation and glioma resection. Neurosurg Focus 2010 28: E1

36. Duffau H, Peggy Gatignol ST, Mandonnet E et al. Intraoperative subcortical stimulation mapping of language pathways in a consecutive series of 115 patients with Grade II glioma in the left dominant hemisphere. J Neurosurg 2008; 109: 461-71.

37. Schweiger H, Kamp HD, Dinkel M. Somatosensory-evoked potentials during carotid artery surgery: experience in 400 operations. Surgery 1991; 109: 602-9

38. Connolly JE. Hume Memorial lecture. Prevention of spinal cord complications in aortic surgery. Am J Surg 1998: 176: 92-101.

39. MacDonald DB, Dong CCJ. Spinal cord monitoring during descending aortic procedures. I: Nuwer $M R$, red. Intraoperativ monitoring of neural function: Handbook of clinical neurophysiology. 8. utg. Atlanta, GA: Elsevier, 2008: 815-28.

40. Møller AR. Anesthesia and its constraints in monitoring motor and sensory system. I: Møller AR, red. Intraoperative neurophysiological monitoring Totowa, NJ: Humana Press, 2006: 279-82.

41. Simon MV Borges L. Intraoperative neurophysiologic monitoring and mapping of the spinal cord. I: Intraoperative neurophysiology. New York, NY: Demos Medical Publishing 2010: 177-266.

42. Sloan TB. Anesthesia and motor evoked potential monitoring. I: Deletis V, Shils JL, red. Neurophysiology in neurosurgery. A modern intraoperative approach. Waltham, MA: Academic Press, 2002: 451-74.

43. Chauvel P, Landre E, Trotier S et al. Electrical stimulation with intracerebral electrodes to evoke seizures. I: Devinsky O, Beric A, Dogali M, red. Electrical and magnetic stimuation of the brain and spinal cord. New York, NY: Raven Press, 1993 115-21.

44. MacDonald DB. Safety of intraoperative transcranial electrical stimulation motor evoked potential monitoring. J Clin Neurophysiol 2002; 19: 416-29.

45. Jones SJ, Harrison R, Koh KF et al. Motor evoked potential monitoring during spinal surgery: responses of distal limb muscles to transcranial cortical stimulation with pulse trains. Electroencephalogr Clin Neurophysiol 1996; 100: 375-83.

46. Møller AR. Evaluating the benefits of intraoperative neurophysiological monitorering. I: Møller AR red. Intraoperative neurophysiological monitoring. Totowa, NJ: Humana Press, 2006: 329-37.

47. Kombos T, Suess O, Brock M. Cost analysis of intraoperative neurophysiological monitoring (IOM). Zentralbl Neurochir 2002; 63: 141-5.

Mottatt 5.1. 2012, første revisjon innsendt 25.4. 2012, godkjent 6.11. 2012. Medisinsk redaktør Siri Lunde. 